\title{
The intersection of school racial composition and student race/ethnicity on adolescent depressive and somatic symptoms
}

\author{
Katrina M. Walsemann ${ }^{\mathrm{a}, *}$, Bethany A. Bell ${ }^{\mathrm{b}}$, Debeshi Maitra ${ }^{\mathrm{c}}$ \\ ${ }^{a}$ Department of Health Promotion, Education and Behavior, University of South Carolina, 800 Sumter Street, Room 314, Columbia, SC 29208, USA \\ ${ }^{\mathrm{b}}$ Educational Psychology, Research, and Foundations, University of South Carolina, SC 29208, USA \\ ${ }^{\mathrm{c}}$ Department of Health Services Policy and Management, University of South Carolina, SC 29208, USA
}

\section{A R T I C L E I N F O}

Article history:

Available online 13 April 2011

\section{Keywords:}

USA

School segregation

Mental health

Discrimination

School attachment

School socio-economic status

Adolescents

Ethnicity

\begin{abstract}
A B S T R A C $T$
Schools are one of the strongest socializing forces in the U.S. and wield considerable influence over individuals' social and economic trajectories. Our study investigates how school-level racial composition, measured by the percentage non-Hispanic white students in a school, affects depressive and somatic symptoms among a representative sample of U.S. adolescents, and whether the association differs by race/ethnicity. We analyzed Wave I data from the US National Longitudinal Study of Adolescent Health, resulting in a sample size of 18,419 students attending 132 junior and senior high schools in 1994/5. After controlling for individual and school characteristics, our multilevel analyses indicated that with increasing percentages of white students at their school, black students experienced more depressive symptoms and a higher risk of reporting high levels of somatic symptoms. After including students' perceptions of discrimination and school attachment, the interaction between black student race and school-level racial composition was no longer significant for either outcome. Our findings suggest that attending predominantly-minority schools may buffer black students from discrimination and increase their school attachment, which may reduce their risk of experiencing depressive and somatic symptoms.

(C) 2011 Elsevier Ltd. All rights reserved.
\end{abstract}

\section{Introduction}

Interest in understanding the potential health effects of the social and physical environment has been renewed in the past decade (Kaplan, 2004; Macintyre, Ellaway, \& Cummins, 2002; Syme, 2008). Given this renewed interest, it is surprising that little research has been conducted investigating the direct health effects of school segregation, even though school segregation plays an important role in the production and perpetuation of racial and social inequities (Bourdieu, 1973; Wells \& Crain, 1994). Indeed, schools are one of the strongest socializing forces in the United States (Hallinan, 2001) and wield considerable influence over individuals' social and economic trajectories. We seek to address this limitation in our study by investigating how school-level racial composition influences depressive and somatic (i.e., physical) symptoms among a representative sample of U.S. adolescents.

\footnotetext{
* Corresponding author.

E-mail address: kwalsema@sc.edu (K.M. Walsemann).
}

\section{Background}

The school environment can have pronounced effects on students' worldviews, their sense of belonging and identity, and their educational opportunities (Lewis, 2003; Yonezawa, Wells, \& Serna, 2002). According to Bourdieu (1973), schools play a complex role in the cultural and social reproduction of social inequalities. They can also act as racializing agents, shaping the worldview of their students (Lewis, 2003). Schools convey information to students in both subtle and overt ways in terms of what race and class mean, who holds power in society, and whose knowledge and beliefs are valued and respected (Lewis, 2003; Oakes, Wells, Jones, \& Datnow, 1997; Yonezawa et al., 2002). Such information is often conveyed through the power structure within the schools (e.g., whites in positions of power), the use of racial code words by school personnel and parents (e.g., "urban", "dangerous"), the extent of attention teachers and administrators demonstrate when racial conflicts occur, and the stereotypes held by school personnel and parents (Lewis, 2003; Mickelson, 2001; Rubin, 2008). For example, Feagin, Vera, and Imani (1996) found that black college students attending predominantly-white U.S. universities reported differential treatment from professors, 
students, and campus police, including but not limited to harassment, verbal assaults, and chilly classroom environments.

School policies also impact students' perceptions of the school environment. Within racially-mixed and predominantlywhite schools, black and Hispanic students are more likely than whites to be tracked into less academically rigorous coursework even at equivalent ability levels (Darling-Hammond, 2004; Mickelson, 2001; Mickelson \& Everett, 2008). Students are often aware of tracking in their school, even if classes are not marked as high-ability (Oakes, 1985). Because of the interplay between social, cultural, and political processes involved in tracking decisions at the school level, tracking often results in the conflation of ability with race/ethnicity (Lewis, 2003; Oakes et al., 1997), which in turn may socialize students to accept their positions in their schools' social hierarchy (Mickelson, 2001). Even in schools which provide some opportunity for track mobility, students who were previously tracked often do not enroll in "high-ability" courses because they have internalized the labels and status attached to them by their peers, teachers, and administrators (Yonezawa et al., 2002).

School segregation significantly impacts the distribution of key educational opportunities and advantages necessary for continued educational achievement. As compared to predominantly-white schools, predominantly-minority schools are more likely to suffer from overcrowded classrooms, utilize outdated books and supplies, offer fewer advanced placement courses, and employ less qualified teachers (Darling-Hammond, 2004; Darling-Hammond \& Post, 2000; Orfield \& Eaton, 1996). Students attending predominantlyminority schools are also more likely to be poor, resulting in higher levels of concentrated poverty in these schools (Orfield, 2001; Orfield \& Lee, 2007).

School racial composition may therefore influence adolescent mental and physical health through at least three, potentially competing, mechanisms. First, school-level socio-economic status (SES) may mediate the relationship between school racial composition and adolescent depressive and somatic symptoms, given that predominantly-white schools are often wealthier (Rothstein, 2000), and can provide an array of educational opportunities that may be unavailable in predominantly-minority schools. To the extent that access to such opportunities keep students engaged and motivated, predominantly-white schools, with their greater access to economic resources, may enhance students' aspirations and achievement, and in turn, promote mental and physical health. Alternatively, low SES schools, which tend to be predominantlyminority, often experience more violence and disorder than high SES schools (Massey, Charles, Lundy, \& Fisher, 2003). Students attending low SES schools may therefore be exposed to greater amounts of stress, which could increase their risk for depressive (Mazza \& Reynolds, 1999) or somatic symptoms (Christiansen, Copeland, \& Stapert, 2008; Natvig, Albrektsen, Anderssen, \& Qvarnstrom, 1999; Rhee, Holditch-Davis, \& Miles, 2005).

Second, the racial composition of the school may create an environment where some students feel valued and respected, whereas others feel marginalized and isolated because of their race/ethnicity (Feagin et al., 1996; Lewis, 2003; Yonezawa et al., 2002). In predominantly-white schools, black and Hispanic students may be exposed to or perceive more discriminatory behavior from teachers and peers. Discrimination, often considered a socially-derived stressor, can subsequently influence mental and physical health (Aneshensel, 1992); perceived discrimination has been associated with greater psychological distress (Brown et al., 2000; Williams, Yan, Jackson, \& Anderson, 1997), depressive symptoms (Pavalko, Mossakowski, \& Hamilton, 2003; Schulz et al., 2006), and health limitations (Gee \& Walsemann, 2009; Pavalko et al., 2003). Adolescents who perceive discriminatory treatment by teachers or staff are at greater risk of experiencing declining mental health (Roeser, Eccles, \& Sameroff, 2000). Furthermore, stress and anxiety (Christiansen et al., 2008; Natvig et al., 1999; Rhee et al., 2005) appear to increase the risk of various somatic symptoms, including headaches, stomachaches, backaches, and morning fatigue (Christiansen et al., 2008). Thus, among black and Hispanic students, perceived discrimination, which may occur more frequently at predominantly-white schools, may also impact levels of somatic symptoms by regularly exposing them to stressful and anxiety-provoking events.

Finally, school racial composition may influence students' attachment to their schools. In general, predominantly-white schools often fail to adequately incorporate the values, interests, or history of people of color into the educational curriculum and mainstream school culture; such exclusions may lead to feelings of alienation and subsequent disengagement from school (Feagin \& Sikes, 1994; Lewis, 2003). This may be one reason why black and Hispanic students often hold more optimistic and pro-school attitudes when they attend predominantly-minority schools (Goldsmith, 2004). Among traditionally disadvantaged students of color, school connectedness is relatively high in predominantly-minority schools and relatively low in racially-mixed schools (McNeely, Nonnemaker, \& Blum, 2002). Given that students who feel connected to their schools are less likely to initiate smoking, get drunk, smoke marijuana, contemplate suicide, initiate sex, or engage in weapons-related violence (McNeely \& Falci, 2004), attending predominantly-white schools may be associated with greater depressive or somatic symptoms among black and Hispanic students.

We examine three hypotheses in this paper. First, we hypothesize that the association between school-level racial composition and depressive or somatic symptoms varies by student race/ ethnicity; black and Hispanic students will experience higher levels of depressive and somatic symptoms in predominantlywhite schools than in predominantly-minority schools. Second, we hypothesize that school-level SES will mediate this relationship. Third, we hypothesize that the differential relationship between school-level racial composition and our dependent variables by student race/ethnicity will be attenuated once we account for students' perceptions of discrimination and attachment to school.

\section{Methods}

We analyzed Wave I (1994/5) restricted data from the National Longitudinal Study of Adolescent Health (Add Health), a nationally representative sample of U.S. adolescents in grades 7 through 12 in 1994/5 (Harris et al., 2009). The Add Health sample is representative of U.S. schools with respect to region of country, urbanicity, school size, school type (private/public), and race/ethnicity. Our analysis utilized three data sources: (1) in-home interview of the student, (2) the parent, and (3) a self-administered questionnaire completed by the school administrator. Institutional review board approval for our study was obtained from the University of South Carolina.

We restricted our analysis to students and schools who were assigned probability weights. We excluded approximately 502 students from the analysis due to item-missingness, most of which was from missingness on the questions pertaining to perceived discrimination and school attachment $(n=365)$. After exclusions, our final analytic sample consisted of 18,419 students (9743 non-Hispanic whites, 3909 non-Hispanic blacks, 3127 Hispanics, 1286 Asian/Pacific Islanders, 148 American Indians, and 206 of other race/ethnicity) attending 132 junior and senior high schools in 1994/5. 


\section{Measures}

\section{Dependent variables}

We measured depressive symptoms using the 19-item Center for Epidemiological Studies Depression Scale (CES-D) available in Add Health (Table 1). Although prior research using Add Health suggests that a reduced 5-item scale may be more applicable to studies of race/ethnicity and nativity (Perreira, Deeb-Sossa, Mullan Harris, \& Bollen, 2005), we found that comparable conclusions could be made, regardless of the number of items used. Therefore, we used the 19-item scale, as much of the research on depressive symptoms uses the longer form of the CES-D, and because utilizing the 19item scale resulted in more variability across schools and was more reliable than the 5 -item scale. Per convention, positively worded items were reverse coded and the nineteen items were summed (Cronbach's $\alpha=0.86$ ). The distribution was slightly skewed; however, results using the original variable were comparable to those using a transformed variable. As a result, we chose to use the original variable in our analyses.

We measured somatic symptoms using twelve indicators of physical symptoms (Table 1 ). The items were extensively pilot tested by Add Health researchers and revised prior to full survey implementation (Udry, 2001). Scores on the summated scale ranged from 0 to 43 (Cronbach's $\alpha=0.80$ ). Exploratory analysis revealed a threshold effect at the 75th percentile. Thus, a binary variable was created such that respondents with scores greater than 12 were categorized as high somatic symptoms and coded 1 and all others were coded 0 . Such dichotomization is consistent with prior research (Rhee et al., 2005), which has found that at higher levels of somatic symptoms convergent validity with social impairment is achieved (Zwaigenbaum, Szatmari, Boyle, \& Offord, 1999).

\section{School racial composition}

We measured school racial composition as the percent of nonHispanic white students at each school, henceforth "percent white students". We calculated percent white students using students' self-reported race/ethnicity in the in-home survey, which we aggregated to the school level using the probability weights provided by Add Health to ensure that the aggregated data were representative of the school. We chose this specification because significant measurement bias for self-reported race/ethnicity exists in the in-school survey (Perez, 2008). Values ranged from 0 to 100. We explored other specifications of school racial composition (e.g., different cut-points, percent non-Hispanic black). These analyses yielded similar results as those presented. To assess the reliability of our measure, we examined the correlation between our aggregated measure and administrative data on school racial composition that was available for 69 schools through the Common Core Data that was linked to Add Health via the Adolescent Health and Academic Achievement (AHAA) study (Muller et al., 2007); the correlation was 0.99 .

\section{Individual-level covariates}

We included age of respondent as a continuous variable. Respondents self-reported their race/ethnicity, which we categorized as non-Hispanic white, non-Hispanic black, Asian/Pacific Islander, American Indian, Hispanic (any race), or other. Respondents were categorized as immigrants if they reported being born outside of the U.S. to non-U.S. citizens. We created a measure of family structure categorized as nuclear (two biological parents), step-family (one biological and one step-parent), female-headed, extended/intergenerational family, and other. Students were asked how much they agreed (on a scale from 1 to 5 , where $1=$ strongly agree and $5=$ strongly disagree) that (1) "teachers at your school treat students fairly"; (2) "you feel you are part of your school"; (3) "you feel close to people at your school"; and (4) "you are happy to be at your school". For item one, students were categorized as disagreed/strongly disagreed versus all else. For the remaining items, students were categorized as agreed/strongly agreed versus all else. We used the first item to capture perceived discrimination and the

Table 1

Description of the 19-item CES-D scale and the 12-item somatic symptom scale.

\begin{tabular}{|c|c|c|}
\hline & 19-item CES-D & Somatic symptoms \\
\hline Question stem & $\begin{array}{l}\text { "How often was each of the following things } \\
\text { true during the past week? You..." }\end{array}$ & $\begin{array}{l}\text { "How often have you had each of the } \\
\text { following conditions in the past } 12 \text { months..." }\end{array}$ \\
\hline \multirow[t]{17}{*}{ Items } & $\begin{array}{l}\text { a) were bothered by things that usually don't bother you. } \\
\text { b) didn't feel like eating, your appetite was poor } \\
\text { c) felt that you could not shake off the blues, even } \\
\text { with help from your family and your friends }\end{array}$ & $\begin{array}{l}\text { a) a headache } \\
\text { b) feeling hot all over suddenly, for no reason } \\
\text { c) a stomachache or upset stomach }\end{array}$ \\
\hline & d) felt that you were just as good as other people ${ }^{a}$ & d) cold sweats \\
\hline & e) had trouble keeping your mind on what you were doing. & e) feeling physically weak, for no reason \\
\hline & f) felt depressed & f) feeling really sick \\
\hline & g) felt that you were too tired to do things & g) waking up feeling tired \\
\hline & h) felt hopeful about the future ${ }^{a}$ & h) dizziness \\
\hline & i) thought your life had been a failure & i) chest pains \\
\hline & j) felt fearful & j) aches, pains, or soreness in your muscles or joints \\
\hline & k) were happy ${ }^{\mathrm{a}}$ & k) trouble falling asleep or staying asleep \\
\hline & 1) talked less than usual & 1) trouble relaxing \\
\hline & m) felt lonely & \\
\hline & n) felt people were unfriendly to you & \\
\hline & o) enjoyed life ${ }^{a}$ & \\
\hline & p) felt sad & \\
\hline & q) felt that people disliked you & \\
\hline & r) felt it was hard to get started doing things & \\
\hline & s) felt life was not worth living & \\
\hline \multirow[t]{5}{*}{ Response set } & $0=$ never or rarely & $0=$ never \\
\hline & $1=$ sometimes & $1=$ just a few times \\
\hline & $2=\mathrm{a}$ lot of the time & $2=$ about once a week \\
\hline & $3=$ most of the time or all of the time & $3=$ almost every day \\
\hline & & $4=$ every day \\
\hline Minimum & 0 & 0 \\
\hline Maximum & 56 & 43 \\
\hline Chronbach's alpha & 0.86 & 0.80 \\
\hline
\end{tabular}

\footnotetext{
${ }^{\text {a }}$ Positively worded item reverse coded.
} 
remaining items to capture school attachment. Finally, we constructed a composite measure of family SES because multivariate indices of SES are more reliable than single-item measures and doing so reduced issues with item-missingness. Family SES was calculated as the mean of standardized ( $z$-score) measures of family poverty, parental educational level, and parental occupation. Positive values represented higher levels of SES (Cronbach's $\alpha=0.66$; Table 2).

\section{School-level covariates}

We created a composite measure of school SES using the same variables included in the family SES variable to provide consistency across SES measures. School SES was calculated as the mean of standardized ( $z$-score) measures of school-level poverty, schoollevel parental education, and school-level parental occupation with higher values representing higher levels of school SES (Cronbach's $\alpha=0.90$; Table 2). Additional covariates included school urbanicity (urban = central city within a CMSA or MSA; suburban $=$ CMSA or MSA with at least 2500 residents but not in central city, rural = all else), region (West, Midwest, South, and Northeast), and school type (public versus private).

\section{Analytic approach}

First, we began with descriptive statistics to understand the data distribution. Next, two-level linear models were examined to investigate the extent to which school racial composition was associated with adolescent depressive symptoms. After examining an unconditional model (not shown), with no predictors, to assess between-school variation in depressive symptoms, we ran a model that only included the main effects of school racial composition and race/ethnicity on depressive symptoms, after adjusting for age, gender, and immigrant status (not shown). Next, to investigate if the relationship between school racial composition and depressive symptoms varied by race/ethnicity we also included cross-level interaction terms for student race/ethnicity by percent white students in Model 1, and all subsequent models. We ran two additional models to determine if the effects of school racial composition were attenuated once other correlated family and school characteristics were included (Models 2 and 3). Finally, we added indicators that measured students' perceptions of discrimination and school attachment (Model 4). In the model building process, we also examined changes in the -2 log-likelihood to assess model fit.

The equation from our final model (Model 4) for predicting depressive symptoms is presented below.

$y=\mathbf{X} \beta+\mathbf{Z} \mu+\epsilon$ where $y$ is an $n \times 1$ vector of responses to the level of depressive symptoms variable, $\mathbf{X}$ is an $n \times p$ matrix containing the fixed effect regressors [i.e., matrix of individual-level covariates (e.g., race/ ethnicity, family SES), school-level covariates (e.g., percent white students), and cross-level interactions (e.g., black $\times$ percent white students)], $\beta$ is a $p \times 1$ vector of fixed-effects parameters, $\mathbf{Z}$ is an $n \times q$ matrix of random effects regressors (i.e., the level- 1 intercept), $\mu$ is a $q \times 1$ vector of random effects, and $\epsilon$ is an $n \times 1$ vector of errors. The assumptions associated with linear mixed models (i.e., normality and homogeneity of variance of level-1 and level2 residuals) were evaluated using a SAS macro created by Bell, Schoeneberger, Morgan, Kromrey, and Ferron (2010) and no substantial violations were noted.

The same model building process was used for predicting high somatic symptoms, except that we specified a two-level generalized linear model using the following equation:

$\operatorname{logit}[P(y=1 \mid \mathbf{X}, \mathbf{Z})]=\mathbf{X} \beta+\mathbf{Z} \mu$

where $\operatorname{logit}[P(y=1 \mid \mathbf{X}, \mathbf{Z})]$ is an $n \times 1$ vector of log-odds that students experience high somatic symptoms. Other than the assumption of independence, which was not violated, based on the study design, no other assumptions needed to be evaluated given the non-linear nature of the models examined.

To make the interpretation of the intercept more meaningful, age was centered at 16 , the approximate mean age of the sample, percent white students at a school was grand mean centered at $67 \%$, and the individual items of perceived discrimination and school attachment were centered at their grand means. Next, to help with the interpretation of the regression coefficients for the variable percent white students, we transformed this variable (original variable/10) such that the reported coefficients represent a $10 \%$ increase in percent white vs. a $1 \%$ increase in percent white. All analyses were weighted to adjust for the complex sample design utilized by Add Health. Descriptive statistics were weighted using the svy commands in Stata v10 (StataCorp, 2007). The two-level models were weighted using Chantala, Blanchette, and Suchindran's (2006) SAS macro to generate appropriate two-level sample weights for use in linear and generalized linear mixed models via Stata's GLLAMM program.

\section{Sensitivity analysis}

We tested the sensitivity of our models to model specification as follows. First, we excluded schools with $0 \%$ and $100 \%$ white students to examine our results after excluding schools at the

Table 2

Description of family SES and school SES variables. ${ }^{\mathrm{a}, \mathrm{b}}$

\begin{tabular}{|c|c|c|}
\hline & Definition & Source \\
\hline \multicolumn{3}{|l|}{ Family SES } \\
\hline Parental occupation & $\begin{array}{l}\text { Seven-level ordinal measure of occupation corresponding to the } 1990 \text { Census } \\
\text { Bureau's occupational classification groupings. Occupations were ordered from } \\
\text { low to high by adapting Erikson and Goldthorpe's class schema in conjunction } \\
\text { with the mean educational level of persons in each occupational grouping (2002). }\end{array}$ & Adolescent in-home Interview \\
\hline Parental education & Aggregated measure of parental education & Parent interview \\
\hline Family poverty & Aggregated measure of family poverty & Parent interview \\
\hline Parental occupation & Aggregated measure of parental occupation & Adolescent in-home Interview \\
\hline
\end{tabular}


extremes of the distribution. The size and direction of the covariates were generally similar as those found in the full sample, but the sample was no longer representative of the school population in 1994/5. Thus, we present the findings from the full sample only. Second, due to potential non-overlap issues (see Fig. 1) we ran race stratified analyses, which mirrored results from our combined analysis using interaction terms. Because the combined analyses allow us to test our hypotheses, we present the results from the combined analyses only.

\section{Results}

\section{Sample characteristics}

The sample consisted of 18,419 adolescents dispersed across 132 schools (density 20-1638). Adolescents were primarily white (67\%), lived in nuclear families (47\%), and had slightly belowaverage family SES $(M=-0.07, \min =-2.23$, $\max =1.45$; Table 3 ). There were slightly more boys than girls (51\% vs. $49 \%$ ), the mean age was 15.9 years $(\min =11.3 ; \max =21.4)$, and $5 \%$ were immigrants. Most adolescents reported feeling close to people at school (67\%), part of their school (73\%), and happy to be at school (66\%), whereas $20 \%$ of students reported that teachers treated students unfairly. On average, most adolescents were enrolled in suburban (59\%), public schools (93\%), that were primarily white (67\%) in their student body composition and had slightly aboveaverage SES $(M=0.16, \min =-1.80, \max =2.15)$.

Significant bivariate racial/ethnic differences in level of depressive symptoms and the proportion reporting high somatic symptoms were noted. We also found bivariate racial/ethnic differences in the percentage of students who reported unfair treatment by teachers, feeling that they were part of their school and that they were happy to be at their school. Consistent with national estimates of school segregation (Orfield \& Lee, 2007), white students attended schools where most students were white (81.9\%), whereas black, Hispanic, Asian/Pacific Islander, and American Indian students attended schools with notably lower proportions of white students (35.6\%, 35.9\%, 37.2\%, and 53\%, respectively).

\section{Two-level linear and generalized linear Models}

We first examined the influence of school racial composition on depressive symptoms in Table 4. Results from Model 1, the least restrictive model, revealed a statistically significant interaction between race (black compared to whites) and the percent of white students in a school $(b=0.311)$. Statistically significant interactions were not found for any other racial/ethnic group included in our study. Next, after adjustments for individual-level covariates (Model 2), the interactive effect between black race and percent white remained significant $(b=0.262)$. Further adjustments for school-level covariates (Model 3) did not attenuate these findings.

As shown in Fig. 2, after controlling for student, family, and school characteristics included in Model 3, black students experienced increasing levels of depressive symptoms as the percentage of white students attending their school increased. As hypothesized, the interaction between black race and percent of white students in a school was no longer statistically significant after controlling for students' perceptions of discrimination and school attachment (Model 4). Model 4 also revealed that students who perceived unfair treatment by teachers experienced higher levels of depressive symptoms, whereas students who felt attached to their school experienced lower levels of depressive symptoms.

Next, following the same model building approach, we examined the influence of school racial composition on high somatic symptoms (Table 5). Like depressive symptoms, after adjusting for individual, family, and school characteristics, the association between the percent of white students at a school and the log-odds of having high somatic symptoms varied for black students

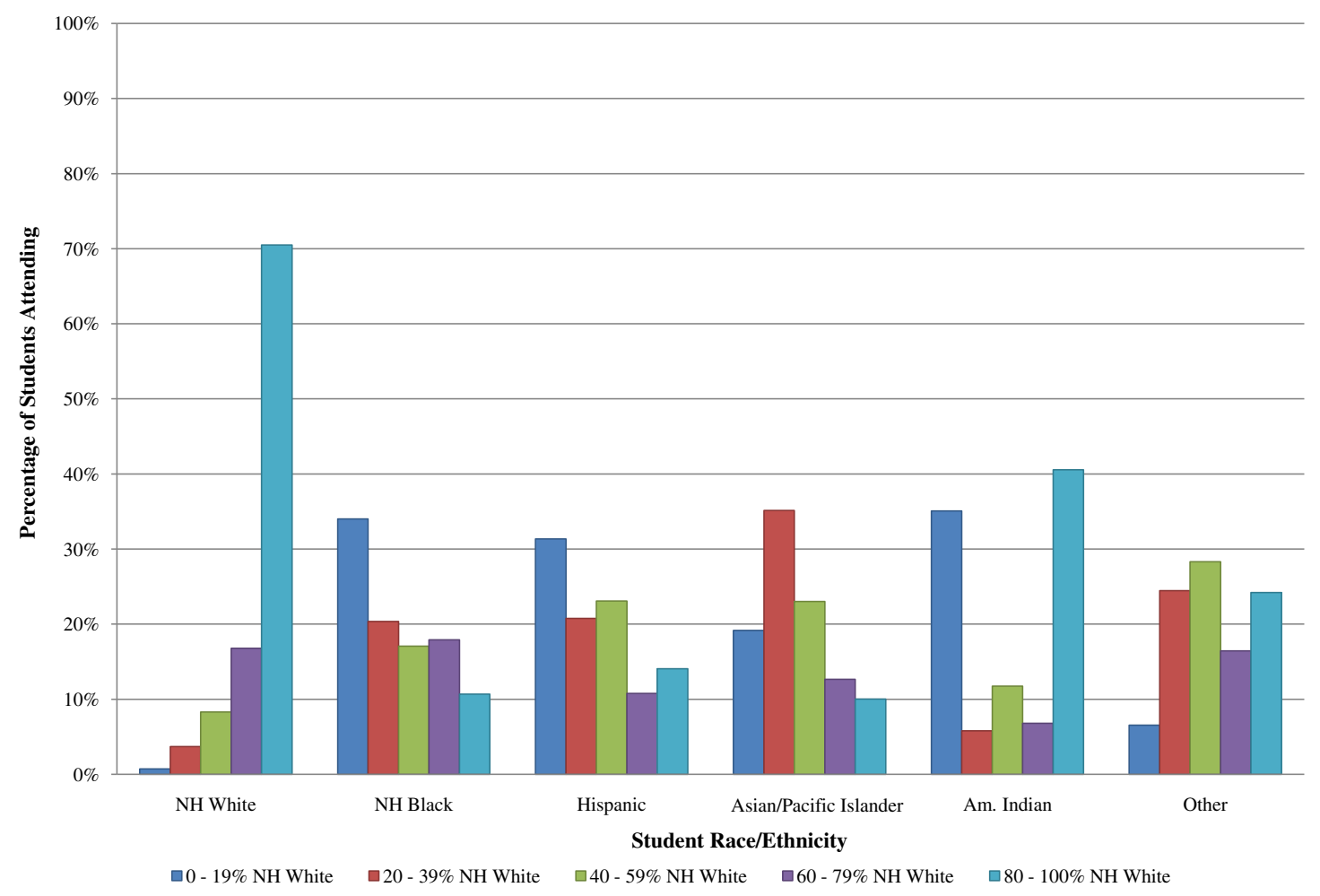

Fig. 1. Percentage of students of each racial/ethnic group attending schools with varying percentages of non-hispanic (NH) white students. 
Table 3

Sample characteristics by student race/ethnicity, $N=18,419$, weighted data. ${ }^{a}$

\begin{tabular}{|c|c|c|c|c|c|c|c|}
\hline & Overall & White & Black & Hispanic & Asian/Pacific Islander & American Indian & Other \\
\hline Depressive symptoms ${ }^{\mathrm{b}, \mathrm{c}, \mathrm{e}}$ & 10.92 & 10.30 & 12.16 & 12.36 & 12.27 & 12.64 & 9.64 \\
\hline High somatic symptoms ${ }^{\mathrm{d}, \mathrm{e}}$ & 0.23 & 0.25 & 0.20 & 0.21 & 0.18 & 0.31 & 0.16 \\
\hline \multicolumn{8}{|l|}{ Individual-level covariates } \\
\hline \multicolumn{8}{|l|}{ Race/Ethnicity } \\
\hline Non-Hispanic White & 0.67 & & & & & & \\
\hline Non-Hispanic Black & 0.16 & & & & & & \\
\hline Hispanic & 0.12 & & & & & & \\
\hline Asian/Pacific islander & 0.04 & & & & & & \\
\hline American Indian & 0.01 & & & & & & \\
\hline Other & 0.01 & & & & & & \\
\hline \multicolumn{8}{|l|}{ Gender $^{\mathrm{d}}$} \\
\hline Female & 0.49 & 0.49 & 0.50 & 0.49 & 0.48 & 0.37 & 0.47 \\
\hline Age (in years) ${ }^{\mathrm{b}, \mathrm{c}, \mathrm{e}}$ & 15.92 & 15.87 & 16.12 & 15.98 & 16.09 & 15.53 & 15.75 \\
\hline Immigrant $\mathrm{d}^{\mathrm{d}, \mathrm{e}}$ & 0.05 & 0.01 & 0.01 & 0.24 & 0.49 & 0.01 & 0.18 \\
\hline Family SES ${ }^{\mathrm{b}, c, e}$ & -0.07 & 0.09 & -0.35 & -0.55 & -0.10 & -0.31 & -0.16 \\
\hline \multicolumn{8}{|l|}{ Family structure $\mathrm{e}^{\mathrm{d}, \mathrm{e}}$} \\
\hline Nuclear & 0.47 & 0.55 & 0.22 & 0.39 & 0.57 & 0.30 & 0.39 \\
\hline Step-family & 0.09 & 0.11 & 0.07 & 0.08 & 0.03 & 0.15 & 0.06 \\
\hline Female-headed household & 0.15 & 0.13 & 0.27 & 0.14 & 0.06 & 0.14 & 0.21 \\
\hline Extended/Intergenerational & 0.22 & 0.16 & 0.37 & 0.34 & 0.29 & 0.32 & 0.24 \\
\hline Other & 0.06 & 0.06 & 0.06 & 0.05 & 0.04 & 0.09 & 0.08 \\
\hline \multicolumn{8}{|l|}{ Perceived discrimination } \\
\hline Unfair treatment by teachers ${ }^{\mathrm{d}, \mathrm{e}}$ & 0.20 & 0.20 & 0.24 & 0.18 & 0.14 & 0.32 & 0.22 \\
\hline \multicolumn{8}{|l|}{ School attachment } \\
\hline Close to people at school $^{\mathrm{d}}$ & 0.67 & 0.67 & 0.64 & 0.67 & 0.73 & 0.61 & 0.63 \\
\hline Part of school ${ }^{\mathrm{d}, \mathrm{e}}$ & 0.73 & 0.74 & 0.74 & 0.67 & 0.71 & 0.63 & 0.67 \\
\hline Happy to be at school ${ }^{\mathrm{d}, \mathrm{e}}$ & 0.66 & 0.65 & 0.64 & 0.72 & 0.73 & 0.53 & 0.63 \\
\hline \multicolumn{8}{|l|}{ School-level covariates } \\
\hline Percent non-Hispanic White ${ }^{b, c, e}$ & 67.00 & 81.89 & 35.55 & 35.94 & 37.16 & 52.98 & 49.92 \\
\hline School SES b,c,e & 0.16 & 0.35 & -0.24 & -0.36 & 0.24 & -0.29 & 0.20 \\
\hline \multicolumn{8}{|l|}{ School type $\mathrm{d}^{\mathrm{d}}$} \\
\hline Private & 0.07 & 0.07 & 0.04 & 0.05 & 0.15 & 0.03 & 0.19 \\
\hline Public & 0.93 & 0.93 & 0.96 & 0.95 & 0.85 & 0.97 & 0.81 \\
\hline \multicolumn{8}{|l|}{ Region $^{\mathrm{d}, \mathrm{e}}$} \\
\hline West & 0.16 & 0.13 & 0.06 & 0.35 & 0.58 & 0.31 & 0.45 \\
\hline Midwest & 0.31 & 0.38 & 0.23 & 0.10 & 0.14 & 0.23 & 0.29 \\
\hline South & 0.39 & 0.35 & 0.64 & 0.40 & 0.13 & 0.20 & 0.19 \\
\hline Northeast & 0.14 & 0.15 & 0.07 & 0.15 & 0.15 & 0.26 & 0.07 \\
\hline \multicolumn{8}{|l|}{ Urbanicity d,e } \\
\hline Rural & 0.16 & 0.19 & 0.13 & 0.04 & 0.02 & 0.40 & 0.03 \\
\hline Urban & 0.26 & 0.18 & 0.31 & 0.61 & 0.29 & 0.12 & 0.36 \\
\hline Suburban & 0.59 & 0.63 & 0.56 & 0.36 & 0.69 & 0.48 & 0.60 \\
\hline
\end{tabular}

a All variables are dummy coded and can be interpreted as proportions, unless otherwise noted.

b Continuous variable, mean presented.

c OLS F-test.

d Chi-square test.

e $p<0.05$.

( $b=0.053, p<0.05$; Model 3), but not for any other racial/ethnic groups included in our analyses.

As shown in Fig. 3, after controlling for individual, family, and school characteristics included in Model 3, the predicted probabilities of reporting high somatic symptoms increased for black students as the percentage of white students at their school increased. Similar to depressive symptoms, after controlling for students' perceptions of discrimination and school attachment (Model 4), the differential relationship between student race, percent of white students in a school, and predicted probabilities of high somatic symptoms was no longer statistically significant. Perceived unfair treatment by teachers was associated with a higher log-odds of high somatic symptoms ( $b=0.40$, Table 5 ), whereas feeling part of or happy to be at school was associated with lower log-odds of high somatic symptoms.

To further understand our findings in relation to our hypotheses we ran post-hoc analyses that examined the influence of percent white students on each of the four individual items of perceptions of discrimination and school attachment and whether the associations differed by race/ethnicity, controlling for all covariates present in Model 3 in Tables 4 and 5. The post-hoc analyses revealed that with increasing percentages of white students, black students were more likely to report unfair treatment by teachers, and less likely to report feeling close to people at school, feeling happy to be at school, or feeling part of the school (results available upon request). This finding, in conjunction with the direct relationships between our dependent variables and students' perceptions of discrimination and school attachment, can help explain the attenuation of the association between black race by percent white students from Model 3 to Model 4, for both dependent variables.

\section{Discussion}

Our analysis of school racial composition and depressive and somatic symptoms indicates three major findings. First, as hypothesized, black students experienced more depressive symptoms and were at greater risk of experiencing high somatic symptoms when attending predominantly-white schools than when attending predominantly-minority schools. The relationship was not significant among other racial/ethnic groups. Second, contrary to our hypothesis, school-level SES did not mediate this relationship. Third, as hypothesized, students' perceptions of 
Table 4

Estimates from two-level linear models predicting depressive symptoms $(N=18,419)$, weighted analyses. ${ }^{a}$

\begin{tabular}{|c|c|c|c|c|}
\hline & $\begin{array}{l}\text { Model } 1^{\mathrm{b}} \\
b(\mathrm{SE})\end{array}$ & $\begin{array}{l}\text { Model } 2^{c} \\
b(\mathrm{SE})\end{array}$ & $\begin{array}{l}\text { Model } 3^{\mathrm{d}} \\
b(\mathrm{SE})\end{array}$ & $\begin{array}{l}\text { Model } 4^{\mathrm{e}} \\
b(\mathrm{SE})\end{array}$ \\
\hline Intercept & $9.58(0.19)^{* * *}$ & $8.96(0.19)^{* * *}$ & $9.15(0.66)^{* * *}$ & $9.25(0.46)^{* * *}$ \\
\hline \multicolumn{5}{|l|}{ Individual-level variables } \\
\hline NH Black & $2.24(0.35)^{* * *}$ & $1.39(0.33)^{* * *}$ & $1.41(0.34)^{* * *}$ & $1.25(0.32)^{* * *}$ \\
\hline Hispanic & $1.11(0.39)^{* *}$ & $0.46(0.38)$ & $0.46(0.36)$ & $0.58(0.38)$ \\
\hline Asian/Pacific Islander & $1.17(0.57)^{*}$ & $1.22(0.55)^{*}$ & $1.22(0.55)^{*}$ & $1.07(0.47)^{*}$ \\
\hline American Indian & $1.85(1.20)$ & $1.15(1.19)$ & $1.13(1.19)$ & $0.47(1.06)$ \\
\hline Other & $-0.68(0.73)$ & $-0.82(0.75)$ & $-0.82(0.75)$ & $-0.96(0.64)$ \\
\hline \multicolumn{5}{|l|}{ Perceived discrimination } \\
\hline Unfair treatment by teachers ${ }^{\mathrm{f}}$ & & & & $1.86(0.21)^{* * *}$ \\
\hline \multicolumn{5}{|l|}{ School attachment } \\
\hline Close to people at school ${ }^{\mathrm{f}}$ & & & & $-1.13(0.17)^{* * *}$ \\
\hline Part of school ${ }^{\mathrm{f}}$ & & & & $-1.93(0.24)^{* * *}$ \\
\hline Happy to be at school ${ }^{\mathrm{f}}$ & & & & $-2.22(0.18)^{* * *}$ \\
\hline \multicolumn{5}{|l|}{ School-level variables } \\
\hline$\%$ NH White ${ }^{g}$ & $-0.128(0.075)$ & $-0.092(0.065)$ & $-0.101(0.067)$ & $-0.051(0.067)$ \\
\hline School SES & & & $-0.019(0.155)$ & $-0.096(0.122)$ \\
\hline \multicolumn{5}{|l|}{ Cross-level interactions } \\
\hline NH Black $\times \%$ NH White & $0.311(0.108)^{* *}$ & $0.262(0.099)^{* *}$ & $0.277(0.101)^{* *}$ & $0.178(0.103)$ \\
\hline Hispanic $\times \%$ NH White & $-0.092(0.134)$ & $-0.045(0.131)$ & $-0.047(0.129)$ & $-0.077(0.120)$ \\
\hline Asian/Pacific Islander $\times \% \mathrm{NH}$ White & $-0.028(0.200)$ & $0.021(0.193)$ & $0.030(0.194)$ & $-0.070(0.178)$ \\
\hline American Indian $\times \%$ NH White & $-0.337(0.326)$ & $-0.406(0.328)$ & $-0.404(0.334)$ & $-0.347(0.273)$ \\
\hline Other $\times \%$ NH White & $0.169(0.216)$ & $0.301(0.230)$ & $0.307(0.232)$ & $0.252(0.222)$ \\
\hline Level-1 variance & 52.86 & 51.60 & 51.61 & 46.87 \\
\hline Level-2 variance & 0.774 & 0.565 & 0.535 & 0.366 \\
\hline$\Delta-2$ log-likelihood ${ }^{\mathrm{h}}$ & $-4523.2 * * *$ & $-55574.0^{* * *}$ & $-369.6^{* * *}$ & $-210951.0^{* * *}$ \\
\hline
\end{tabular}

${ }^{*} p<0.05,{ }^{* *} p<0.01,{ }^{* * *} p<0.001$.

a Unconditional model level 2 variance $=1.41$.

b Adjusted for age (centered at 16), gender, nativity.

c Adjusted for Model 1 covariates plus family structure and family SES.

d Adjusted for Model 2 covariates plus school urbanicity school type, and region.

e Adjusted for Model 3 covariates.

f Student perception of discrimination and attachment variables centered at grand means.

g Percent white students centered at $67 \%$ and divided by 10 .

${ }^{\mathrm{h}}$ Change in the -2LL contrasts Model 1 to a model without the race/ethnicity by school racial composition interactions (not shown); Model 2 to Model 1 ; Model 3 to Model 2 , and Model 4 to Model 3.

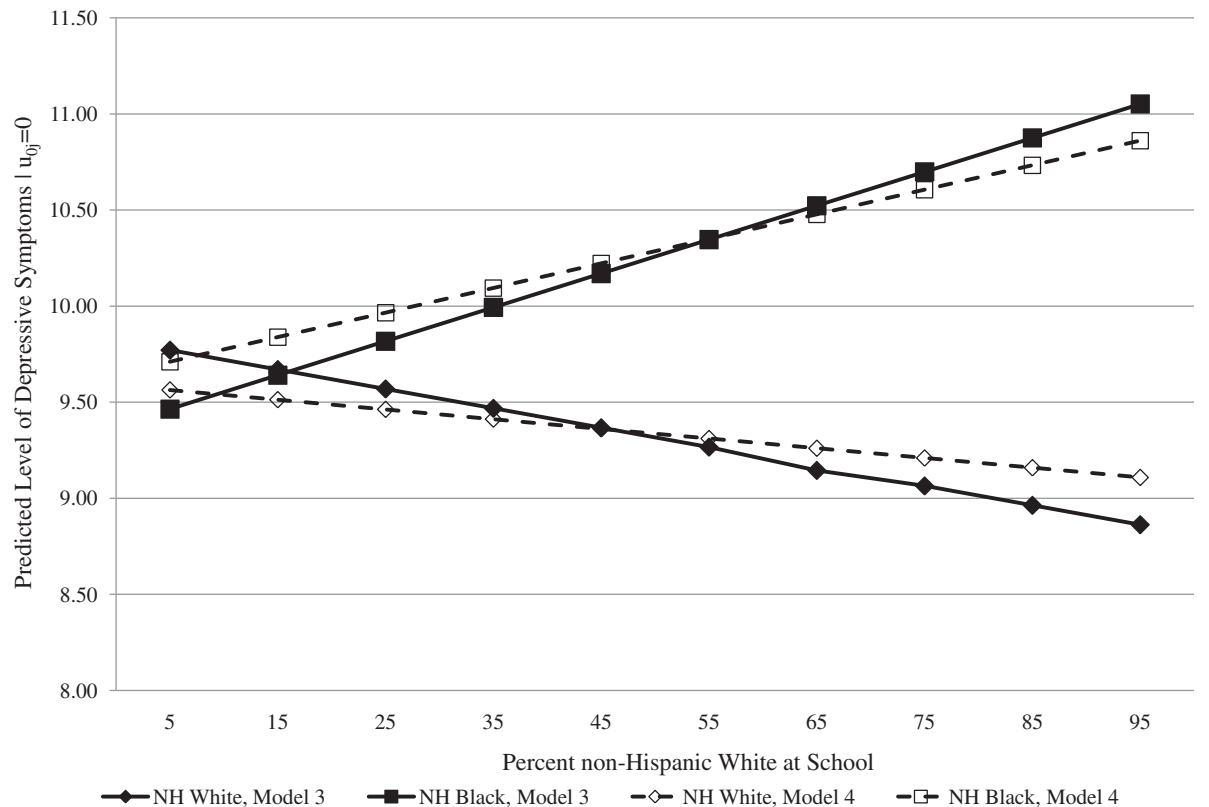

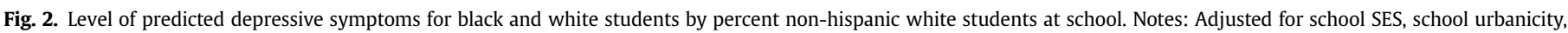

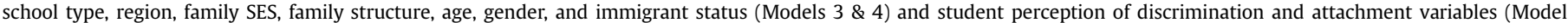

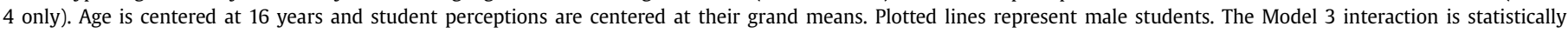
significant at the 0.05 level; however, the Model 4 interaction is not. 
Table 5

Estimates from two-level generalized linear models predicting high somatic symptoms $(N=18,419)$, weighted analysis. ${ }^{\mathrm{a}, \mathrm{b}}$

\begin{tabular}{|c|c|c|c|c|}
\hline & $\begin{array}{l}\text { Model } 1^{c} \\
b(\mathrm{SE})\end{array}$ & $\begin{array}{l}\text { Model } 2^{\mathrm{d}} \\
b(\mathrm{SE})\end{array}$ & $\begin{array}{l}\text { Model } 3^{\mathrm{e}} \\
b(\mathrm{SE})\end{array}$ & $\begin{array}{l}\text { Model } 4^{\mathrm{f}} \\
b(\mathrm{SE})\end{array}$ \\
\hline Intercept & $-1.36(0.06)^{* * *}$ & $-1.48(0.06)^{* * *}$ & $-1.44(0.11)^{* * *}$ & $-1.48(0.10)^{* * *}$ \\
\hline \multicolumn{5}{|l|}{ Individual-level variables } \\
\hline \multicolumn{5}{|l|}{ Race/Ethnicity (Ref = NH White) } \\
\hline NH Black & $-0.10(0.10)$ & $-0.18(0.10)$ & $-0.18(0.10)$ & $-0.21(0.10)^{*}$ \\
\hline Hispanic & $-0.17(0.10)$ & $-0.20(0.11)$ & $-0.22(0.11)^{*}$ & $-0.21(0.11)$ \\
\hline Asian/Pacific Islander & $-0.37(0.20)$ & $-0.35(0.19)$ & $-0.36(0.20)$ & $-0.38(0.19)^{*}$ \\
\hline American Indian & $0.27(0.28)$ & $0.23(0.28)$ & $0.22(0.28)$ & $0.11(0.28)$ \\
\hline Other & $-0.31(0.31)$ & $-0.32(0.31)$ & $-0.32(0.32)$ & $-0.35(0.32)$ \\
\hline \multicolumn{5}{|l|}{ Perceived discrimination } \\
\hline Unfair treatment by teachers ${ }^{g}$ & & & & $0.40(0.06)^{* * *}$ \\
\hline \multicolumn{5}{|l|}{ School attachment } \\
\hline Close to people at school ${ }^{g}$ & & & & $-0.10(0.06)$ \\
\hline Part of school ${ }^{g}$ & & & & $-0.23(0.06)^{* * *}$ \\
\hline Happy to be at school ${ }^{g}$ & & & & $-0.47(0.06)^{* * *}$ \\
\hline \multicolumn{5}{|l|}{ School-level variables } \\
\hline$\%$ NH White & $-0.000(0.017)$ & $0.006(0.02)$ & $-0.001(0.018)$ & $0.007(0.018)$ \\
\hline School SES & & & $0.078(0.046)$ & $0.069(0.045)$ \\
\hline \multicolumn{5}{|l|}{ Cross-level interactions } \\
\hline NH Black $\times \%$ NH White & $0.060(0.026)^{*}$ & $0.054(0.026)^{*}$ & $0.053(0.026)^{*}$ & $0.036(0.027)$ \\
\hline Hispanic $\times \%$ NH White & $0.009(0.030)$ & $0.005(0.029)$ & $0.001(0.029)$ & $-0.008(0.030)$ \\
\hline Asian/Pacific Islander $\times \% \mathrm{NH}$ White & $-0.045(0.050)$ & $-0.042(0.050)$ & $-0.038(0.050)$ & $-0.055(0.050)$ \\
\hline American Indian $\times \%$ NH White & $0.019(0.058)$ & $0.010(0.057)$ & $0.005(0.057)$ & $0.009(0.061)$ \\
\hline Other $\times \%$ NH White & $0.080(0.084)$ & $0.092(0.085)$ & $0.090(0.085)$ & $0.089(0.087)$ \\
\hline Level-2 variance & 0.045 & 0.044 & 0.039 & 0.039 \\
\hline$\Delta-2$ log-likelihood ${ }^{\mathrm{i}}$ & $-1411.8^{* * *}$ & $-5698.4^{* * *}$ & $-2021.0^{* * *}$ & $-56476.4^{* * *}$ \\
\hline
\end{tabular}

${ }^{*} p<0.05,{ }^{* *} p<0.01,{ }^{* * *} p<0.001$.

a Log-odds and standard errors presented.

b Unconditional model level 2 variance $=0.06$.

c Adjusted for age (centered at 16), gender, nativity.

d Adjusted for Model 1 covariates plus family structure and family SES.

e Adjusted for Model 2 covariates plus school urbanicity, school type, and region.

f Adjusted for Model 3 covariates.

g Student perception of discrimination and attachment variables centered at grand means.

h Percent white students centered at $67 \%$ and divided by 10 .

${ }^{\mathrm{i}}$ Change in the -2LL contrasts Model 1 to a model without the race/ethnicity by school racial composition interactions (not shown); Model 2 to Model 1 ; Model 3 to Model 2 , and Model 4 to Model 3.

discrimination and school attachment attenuated the interactive associations between race (black vs. white), percent white students at school, and depressive and somatic symptoms.

Our findings are consistent with qualitative research suggesting that black students often feel alienated and isolated when attending predominantly-white schools (Feagin et al., 1996; Lewis, 2003). The fact that our findings were explained by students' perceptions of discrimination and school attachment lends additional support for this interpretation. Although predominantlywhite schools are less likely to experience high levels of concentrated poverty, violence, or disorder, and are more likely to have access to economic resources that allow them to provide more educational opportunities to their students, it is possible that the most salient aspect in terms of adolescent depressive and somatic symptoms is students' perceptions of how they are treated by peers and teachers. Adolescence is a time when peer acceptance is prominent, and as such, adolescents are highly likely to internalize the views of their peers and integrate these views into their own self-concepts (Crosnoe \& McNeely, 2008).

Stress is positively associated with high levels of somatic symptoms (Christiansen et al., 2008; Rhee et al., 2005). In models not adjusting for students' perceptions of discrimination and school attachment, the predicted probability of experiencing high somatic symptoms increased for blacks with increasing percentages of white students at the school. However, after adjusting for these variables, this relationship dissipated. These findings suggest that one mechanism through which predominantly-white schools might increase somatic symptoms among black students is through exposure to daily micro-aggressions that may occur more readily at predominantly-white schools. Feagin and Sikes (1994) define these micro-aggressions as "blatant, subtle, and covert actions taken by white people, willfully or half-consciously, to exclude, restrict, or otherwise harm black people" (p. 20). Given that racially-mixed and predominantly-white schools are more likely to resegregate black students into less rigorous coursework in an effort to appease white parents (Wells \& Serna, 1996), school policies influenced by racial politics are one such micro-aggression that may increase the stress and anxiety of black students attending these schools.

It is plausible that predominantly-white schools have shortterm negative effects, but long-term protective effects for black students. Because a greater number of students who attend predominantly-white schools are middle- and upper-class, these schools can often provide access to greater educational and occupational networks that may help their students gain admission to colleges and well-paying jobs. These loose networks have been shown to increase the educational attainment of black students and decrease their occupational segregation in adulthood (Wells \& Crain, 1994). As such, the potential long-term benefits of attending predominantly-white schools on individuals' social and economic trajectories may not be fully perceived until adulthood. Given the cross-sectional nature of our study, we were unable to test this hypothesis, but such questions are an important next step in understanding the long-term effects of school racial composition on mental and physical health.

Our findings for Hispanic students did not support our initial hypothesis that they would experience greater depressive and 


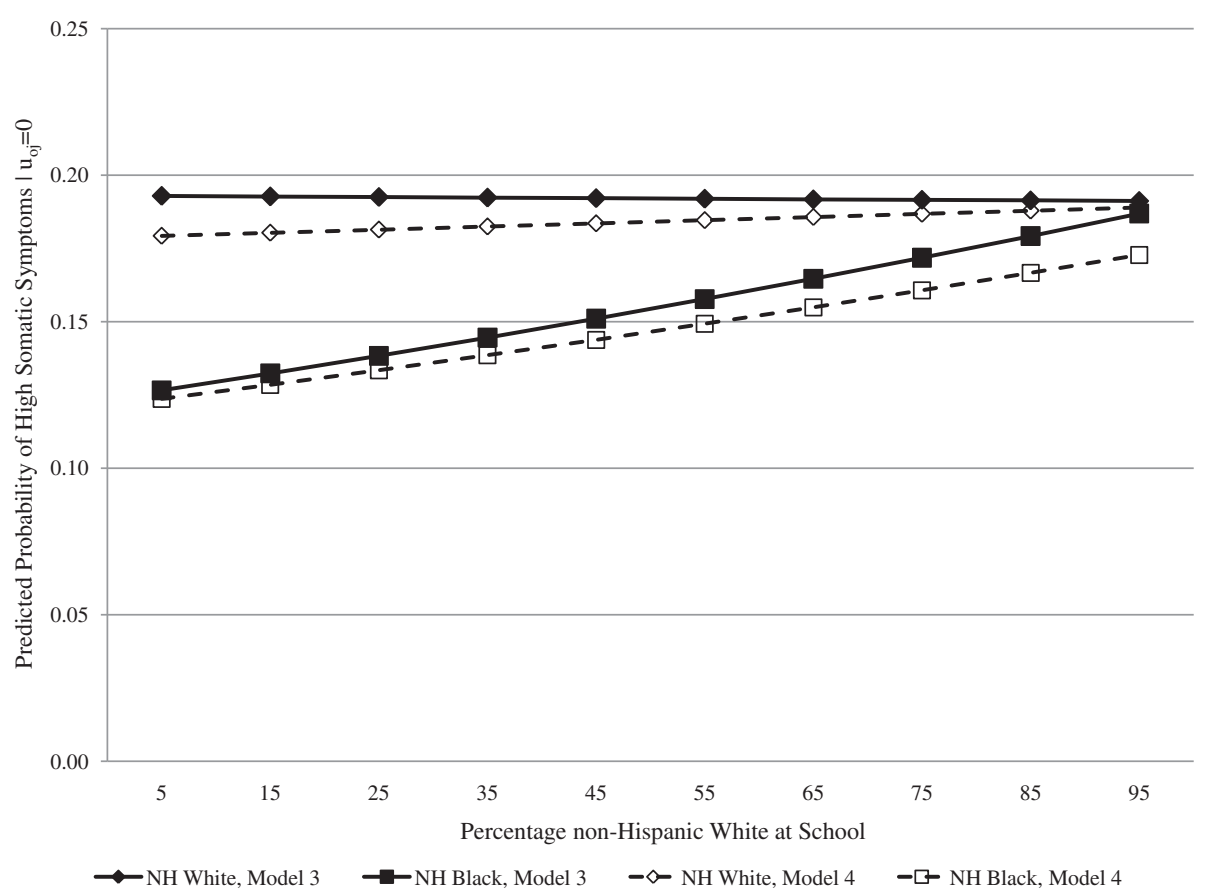

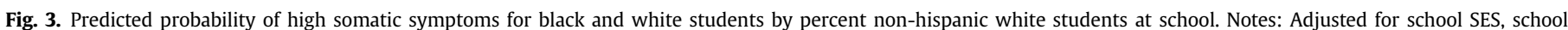

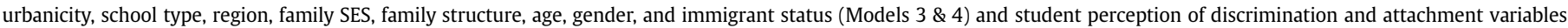

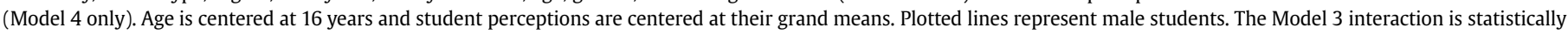
significant at the 0.05 level; however, the Model 4 interaction is not.

somatic symptoms in predominantly-white schools as compared to predominantly-minority schools. We also found that the percentage of white students at a school had a negligible effect on Asian/Pacific Islander or American Indian students' levels of depressive or somatic symptoms. It is possible that the school environment plays a less pronounced role in depressive and somatic symptoms among Hispanic, Asian/Pacific Islander, and American Indian students than among black students and that other contexts and forms of support (e.g., family, peer groups) may be more important for these students. Given the unique history of school segregation experienced by blacks in the U.S., it is also plausible that black students experience greater levels of discrimination or are more negatively impacted by discriminatory school policies (e.g., academic ability grouping) than are other minority students. Alternatively, Hispanic, Asian/Pacific Islander, and American Indian students may be affected by different aspects of their school environment as compared to black students. An important extension of this study would be to investigate if other aspects of the school community influence the health of Hispanic, Asian/Pacific Islander, and American Indian students, and if peer group or family influences modify this relationship.

Considerable heterogeneity exists within the Hispanic, Asian/ Pacific Islander, and American Indian student population. Small sample sizes and unmeasured heterogeneity coupled with less dispersion of Hispanics, Asian/Pacific Islanders and American Indians across schools may have also impacted our results. Future studies may need to sample not only larger numbers of Hispanic, Asian/Pacific Islander, and American Indian adolescents, but may also need to sample a greater number of U.S. schools in order to determine if our results are robust.

\section{Limitations}

First, our sample was designed to be representative of U.S. students who were enrolled in junior and senior high school in 1994/
5. As such, we can only generalize to this population. However, to our knowledge, Add Health is the only nationally representative schoolbased survey in the U.S. that allows for the analysis of school-level associations with adolescent depressive and somatic symptoms. Second, we used cross-sectional data and cannot make causal claims about the relationship between school racial composition and depressive and somatic symptoms, or investigate if school racial composition has long-term effects on depressive and somatic symptoms. Third, depressive and somatic symptoms constitute only two dimensions of health. Other outcomes (e.g., externalizing behaviors, anxiety) should be explored in future research. However, it is important to emphasize that our findings were similar across measures of depressive and somatic symptoms, even though the reference period differed across measures, lending additional support for our findings. Finally, although adolescents navigate many social settings on a daily basis, our analyses and results are limited to the school environment. Other social environments also play a role in adolescents' mental and physical health (Aneshensel \& Sucoff, 1996; Cook, Herman, Phillips, \& Settersten, 2002; Leventhal \& Brooks-Gunn, 2003). However, we chose to limit our analyses to schools given the finding that schools are one of the strongest socializing forces during adolescence. Additional research is needed to more fully understand how different social environments (e.g., neighborhoods and schools) interact to affect adolescent health.

\section{Conclusion}

In closing, our study provides preliminary evidence that school racial composition influences the mental and physical health of black students. Attending predominantly-minority schools may buffer black students from daily micro-aggressions that may occur more often at predominantly-white schools. This is not to say that school segregation is good per se; indeed, the underlying and historical factors resulting in the continued perpetuation of school 
segregation is inherently unjust. However, given the continued significance of race in the U.S. society, school environments that promote feelings of acceptance, belonging, and identity may be particularly important for black students, and may be more readily found for black students at predominantly-minority schools.

\section{Acknowledgements}

An earlier version of this paper was presented at the 2010 Annual Meeting of the Population Association of America. This research was supported by the University of Michigan's Robert Wood Johnson Foundation Health \& Society Scholars Program Small Grant \#N008885.

This research used data from the National Longitudinal Study of Adolescent Health, a program project by Kathleen Mullan Harris and designed by J. Richard Udry, Peter S. Bearman, and Kathleen Mullan Harris at the University of North Carolina, Chapel Hill, and funded by grant P01-HD31921 from the Eunice Kennedy Shriver National Institute of Child Health and Human Development, with cooperative funding from 23 other federal agencies and foundations. Special acknowledgment is due Ronald R. Rindfuss and Barbara Entwisle for assistance in the original design. Information on how to obtain the Add Health data files is available on the Add Health Website (http://www.cpc.unc.edu/addhealth).

This research also used data from the Adolescent Health and Academic Achievement study, which was funded by a grant (R01 HD040428-02, Chandra Muller, PI) from the National Institute of Child Health and Human Development, and a grant (REC0126167, Chandra Muller, PI, and Pedro Reyes, Co-PI) from the National Science Foundation. This research was also supported by grant 5 R24 HD042849, Population Research Center, awarded to the Population Research Center at the University of Texas at Austin by the Eunice Kennedy Shriver National Institute of Health and Child Development.

No direct support was received from grants P01-HD31921, R01 HD040428-02, or 5 R24 HD042849 for this analysis.

Opinions reflect those of the authors and do not necessarily reflect those of the granting agencies.

\section{References}

Aneshensel, C. S., \& Sucoff, C. A. (1996). The neighborhood context of adolescent mental health. Journal of Health and Social Behavior, 37(4), 293-310.

Aneshensel, C. S. (1992). Social stress: theory and research. Annual Review of Sociology, 18, 15-38.

Bell, B. A., Schoeneberger, J. A., Morgan, G. B., Kromrey, J. D., \& Ferron, J. M. (2010). Fundamental diagnostics for two-level mixed models: The SAS ${ }^{\circledR}$ macro MIXED_DX. SAS global forum 2010 proceedings. Retrieved from. http://support.sas.com/ resources/papers/proceedings10/201-2010.pdf.

Bourdieu, P. (1973). Cultural reproduction and social reproduction. In R. Brown (Ed.), Knowledge, education, and cultural change (pp. 71-112). London: Tavistock Publications Limited.

Brown, T. N., Williams, D. R., Jackson, J. S., Neighbors, H. W., Torres, M., Sellers, S. L., et al. (2000). "Being black and feeling blue": the mental health consequences of racial discrimination. Race and Society, 2(2), 117-131.

Chantala, K., Blanchette, D., \& Suchindran, C. M. (2006). Software to compute sampling weights for multilevel analysis. Chapel Hill: Carolina Population Center, UNC. Retrieved from. http://www.cpc.unc.edu/restools/data_analysis/ml_sampling_weights.

Christiansen, L. M., Copeland, E. P., \& Stapert, E. B. (2008). Predictors of somatic symptoms in younger rural adolescents. Adolescence, 43(172), 791-806.

Cook, T. D., Herman, M. R., Phillips, M., \& Settersten, J. R. A. (2002). Some ways in which neighborhoods, nuclear families, friendship groups, and schools jointly affect changes in early adolescent development. Child Development, 73(4), 1283-1309.

Crosnoe, R., \& McNeely, C. (2008). Peer relations, adolescent behavior, and public health research and practice. Family \& Community Health, 31, S71-80.

Darling-Hammond, L., \& Post, L. (2000). Inequality in teaching and schooling: supporting high-quality teaching and leadership in low-income schools. In R. Kahlenberg (Ed.), A notion at risk: Preserving public education as an engine for social mobility (pp. 127-167). New York: The Century Foundation Press.

Darling-Hammond, L. (2004). Inequality and the right to learn: access to qualified teachers in California's public schools. Teachers College Record, 106(10), 1936-1966.
Day, J., \& Curry, A. (1996). Educational attainment in the United States: March 1995 (P20-489). Washington, D.C.: US Census Bureau. Retrieved from. http://www. census.gov/prod/2/pop/p20/p20-489.pdf.

Erikson, R., \& Goldthorpe, J. H. (2002). Intergenerational inequality: a sociological perspective. The Journal of Economic Perspectives, 16(3), 31-44.

Feagin, J. R., \& Sikes, M. P. (1994). Living with racism: The black middle-class experience. Boston: Beacon Press.

Feagin, J. R., Vera, H., \& Imani, N. (1996). The agony of education. New York Routledge.

Gee, G. C., \& Walsemann, K. M. (2009). Does health predict reports of racia discrimination or do reports of discrimination predict health? Findings from the National Longitudinal Study of Youth. Social Science \& Medicine, 69(9). pp. 1676-1684

Goldsmith, P. A. (2004). Schools' racial mix, students' optimism, and the blackwhite and Latino-white achievement gaps. Sociology of Education, 77, 121-147.

Hallinan, M. T. (2001). Sociological perspectives on black-white inequalities in American schooling. Sociology of Education, 74(Extra issue), 50-70.

Harris, K. M., Halpern, C. T., Whitsel, E., Hussey, J., Tabor, J., Entzel, P., et al. (2009). The National Longitudinal Study of Adolescent Health: Research design. Chape Hill: Carolina Population Center, UNC. Retrieved from. http://www.cpc.unc.edu/ projects/addhealth/design.

Kaplan, G. A. (2004). What's wrong with social epidemiology, and how can we make it better? Epidemiologic Reviews, 26(1), 124-135.

Leventhal, T., \& Brooks-Gunn, J. (2003). Moving to opportunity: an experimental study of neighborhood effects on mental health. American Journal of Public Health, 93(9), 1576-1582.

Lewis, A. E. (2003). Race in the schoolyard: Negotiating the color line in classrooms and communities. Piscataway, NJ: Rutgers University Press.

Macintyre, S., Ellaway, A., \& Cummins, S. (2002). Place effects on health: how can we conceptualise, operationalise and measure them? Social Science E' Medicine, 55 , 125-139.

Massey, D. S., Charles, C. Z., Lundy, G. F., \& Fischer, M. J. (2003). Source of the river: The social origins of freshmen at America's selective colleges and universities. Princeton, NJ: Princeton University Press.

Mazza, J. J., \& Reynolds, W. M. (1999). Exposure to violence in young inner-city adolescents: relationships with suicidal ideation, depression, and PTSD symptomatology. Journal of Abnormal Child Psychology, 27(3), 203-213.

McNeely, C. A., \& Falci, C. (2004). School connectedness and the transition into and out of health-risk behavior among adolescents: a comparison of social belonging and teacher support. Journal of School Health, 74(7), 284-292.

McNeely, C. A. Nonnemaker, J. M., \& Blum, R. W. (2002). Promoting schoo connectedness: evidence from the National Longitudinal Study of Adolescent Health. Journal of School Health, 72(4), 138-146.

Mickelson, R. A., \& Everett, B. J. (2008). Neotracking in North Carolina: how high school courses of study reproduce race and class-based stratification. Teachers College Record, 110(3), 535-570.

Mickelson, R. A. (2001). Subverting Swann: first- and second-generation segregation in the Charlotte-Mecklenburg schools. American Educational Research Journal, 38(2), 215-252.

Muller, C., Pearson, J., Riegle-Crumb, C., Requejo, J. H., Frank, K. A., Schiller, K. S., et al. (2007). National Longitudinal study of adolescent health: Wave III data: Design and implementation of the Adolescent Health and Academic Achievement Study. Chapel Hill: Carolina Population Center, UNC. Retrieved from. http://www.laits. utexas.edu/ahaa/docs/StudyDesign_2007.pdf.

Natvig, G. K., Albrektsen, G., Anderssen, N., \& Qvarnstrom, U. (1999). School-related stress and psychosomatic symptoms among school adolescents. Journal of School Health, 69(9), 362

Oakes, J., Wells, A. S., Jones, M., \& Datnow, A. (1997). Detracking: the social construction of ability, cultural politics, and resistance to reform. Teachers College Record, 98, 482-510.

Oakes, J. (1985). Keeping track: How schools structure inequality. New Haven: Yale University Press.

Orfield, G., \& Eaton, S. E. (1996). Dismantling desegregation: The quiet reversal of Brown $v$ Board of Education. New York: W.W. Norton \& Company, Inc.

Orfield, G. \& Lee, C. (2007). Historic reversals, accelerating resegregation, and the need for new integration strategies. A report of the civil rights project. Los Angeles: UCLA. Retrieved from. http://www.civilrightsproject.ucla.edu/research/deseg/ reversals_reseg_need.pdf.

Orfield, G. (2001). Schools more separate: Consequences of a decade of rese gregation. Cambridge, MA: The Civil Rights Project at Harvard University. Retrieved from. http://www.civilrightsproject.ucla.edu/research/deseg/ Schools_More Separate.pdf.

Pavalko, E. K., Mossakowski, K. N., \& Hamilton, V. J. (2003). Does perceived discrimination affect health? Longitudinal relationships between work discrimination and women's physical and emotional health. Journal of Health and Social Behavior, 44(1), 18-33.

Perez, A. D. (2008). Who is hispanic? Shades of ethnicity among Latino/a youth. In C. Gallagher (Ed.), Racism in post-race America: New theories, new directions (pp. 17-35). Chapel Hill, NC: Social Forces.

Perreira, K. M., Deeb-Sossa, N., Mullan Harris, K., \& Bollen, K. (2005). What are we measuring? An evaluation of the CES-D across race/ethnicity and immigrant generation. Social Forces, 83(4), 1567-1602.

Rhee, H., Holditch-Davis, D., \& Miles, M. S. (2005). Patterns of physical symptoms and relationships with psychosocial factors in adolescents. Psychosomatic Medicine, 67(6), 1006-1012. 
Roeser, R. W., Eccles, J. S., \& Sameroff, A. J. (2000). School as a context of early adolescents' academic and social-emotional development: a summary of research findings. The Elementary School Journal, 100(5), 443-471.

Rothstein, R. (2000). Equalizing education resources on behalf of disadvantaged children. In R. Kahlenberg (Ed.), A notion at risk: Preserving education as an engine for social mobility (pp. 31-92). New York: The Century Foundation Press.

Rubin, B. (2008). Detracking in context: how local constructions of ability complicate equity-geared reform. Teachers College Record, 110(3), 646-699.

Schulz, A. J., Gravlee, C. C., Williams, D. R., Israel, B. A., Mentz, G., \& Rowe, Z. (2006) Discrimination, symptoms of depression, and self-rated health among African American women in detroit: results from a longitudinal analysis. American Journal of Public Health, 96(7), 1265-1270.

Stata Corp. (2007). Stata statistical software. Release 10.0. College Station, TX.

Syme, S. L. (2008). Reducing racial and social-class inequalities in health: the need for a new approach. Health Affairs, 27(2), 456-459.
Udry, R. (2001). References, instruments, and questionnaires consulted in the development of the Add Health in-home adolescent interview. Chapel Hill: Carolina Population Center, UNC. Retrieved from. http://www.cpc.unc.edu/projects/ addhealth/data/using/guides/refer.pdf.

Wells, A. S., \& Crain, R. L. (1994). Perpetuation theory and the long-term effects of school desegregation. Review of Educational Research, 64(4), 531-555.

Wells, A. S., \& Serna, I. (1996). The politics of culture: understanding local political resistance to detracking in racially mixed schools. Harvard Educational Review, 66(1), 93-118.

Williams, D. R., Yan, Y., Jackson, J. S., \& Anderson, N. B. (1997). Racial differences in physical and mental health: socio-economic status, stress and discrimination. Journal of Health Psychology, 2(3), 335-351.

Yonezawa, S., Wells, A. S., \& Serna, I. (2002). Choosing tracks: "Freedom of Choice" in detracking schools. American Educational Research Journal, 39(1), 37-67.

Zwaigenbaum, L., Szatmari, P., Boyle, M. H., \& Offord, D. R. (1999). Highly somatizing young adolescents and the risk of depression. Pediatrics, 103(6), 1203-1209. 